Kong. Res. J. 1(2):1-3, 2014

Kongunadu Arts and Science College, Coimbatore

\title{
TRANSFORMATION OF THE SELF: A PATH TO REDEMPTION IN ALICE WALKER'S THE THIRD LIFEOF GRANGE COPELAND
}

\author{
Charrumathi, N.R*. \\ Department of English, Kongunadu Arts and Science College, Coimbatore \\ *E.mail : narayanacharu@gmail.com
}

\begin{abstract}
Alice Walker emphasis on the transformation of the self along with the changes in the society is explicitly depicted in her works. The protagonist and the important characters undergo phenomenal change, an inevitable change to better the status of the black men and women. The discrimination of the black by the white society can be obliterated only by the mutual compatibility of the black men and women. Women characters transform from passive and submissive nature to active and rebellious. She believes in the possibility of men becoming androgynous as well. Walker's conviction that emancipation of women is possible only when men mellow and transform themselves, is exemplified in her debut novel The Third Life of Grange Copeland.
\end{abstract}

Keywords: Alice Walker, The third life of Grange Copeland.

Alice Walker feels that the liberation of women is attainable only when men start understanding the sufferings of women as their own; when men change or reform or be responsible for the liberation of the entire race without excluding women from their fight for liberation;when "New man", put love in front as Christ, as she explains it in her poem, "The Abduction of Saints." In her interview with Winfrey, she told, "There is no heaven. This is it. We're already in heaven, you know, and so in order... for the earth to survive, we have to acknowledge each other as part of the family, the same family, and also reaffirm those things in ourselves and in other people that we've been brought up to fear or to hate(qtd. in Winfrey)."

According to Walker, the society is invariably a factor which causes change in a person and therefore the change should simultaneously happen both to the person and to the society. The struggle for liberation of the community and the individual should be in juxtaposition to make it whole. Precisely, the change should be both inner as well as outer. The black person thinks that he is not capable of being responsible for any of his actions or behaviour, because he thinks that only white folks are to be blamed for all his reactions and change. The black people should shed shame and develop selflove to accept responsibility of their own identity, their own lives instead of blaming the white folks and white society for their plight.

In Walker's novels, the men redeem themselves and grow. They turn inward to analyze the moral in their lives. Though they were subservient and powerless, after redemption they grow powerful and shed their slavery to gain their identity and individuality. Men especially mellow and save their internal morality and dignity, autonomy and balance, integrity and honour. Walker's conviction that emancipation of women is possible only when men mellow and transform themselves, is exemplified in her debut novel The Third Life of Grange Copeland. Men undergo metamorphosis. Copeland comes back from his "second life" in New York, as a new responsible man and a loving grandfather. Brutality of men is due to their incapability. The subservience, subjugation and powerlessness they suffer under the whites make them stretch themselves to the furthest point of male dominance and brutality. The victimizer is himself the victim of the white. Harold Bloomsays, "For the most part, the Black men in Walker's world are in need of redemption from the racism, oppression, and sexism still rampant in our society. They are in need of liberation from the near-zero images of themselves which has been propagated through the literature and the culture" (Bloom 17).

Walker is sympathetic toward her black male characters as they grow older. Her images of young black male brutality toward women are not surprising; violence was a fact of life in Eatonton in general and in her own family in particular. In an interview with David Bradley, Walker recalls,

I knew both my grandfathers, and they were just doting, indulgent, sweet old men. I just loved them both and they were crazy about me. However, as young men, middle-aged men, they were... brutal. One grandfather knocked my grandmother out of a window. He beat one of his children so severely that the child had epilepsy. Justa horrible, horrible man. But when I knew him, he was a sensitive, wonderful man (www.nytimes.com) 
Her critics charged her with presenting a grossly negative image of Black men, who were portrayed as mean, cruel, or violent, entirely without redeeming qualities. Walker's criticism of black men is not a sign of enmity but a love for the well-being of the common humanity. Her futuristic outlook is seen in her desire to bring harmony between men and women by improving human character.

Walker'sThe Third Life of Grange Copeland, signifies that Grange Copeland, the protagonist, has three lives and it covers the three generations of the Copeland family and a period of American history from the 1920 s to the 1960s. Grange's first life is dominated by his response to an oppressive, dehumanizing social structure which deprives him of his personhood and causes him to abuse his wife Margaret and to deny parental love and care to his son, Brownfield. The novel opens, in Grange's "first life" with his wife Margaret and their only child, Brownfield, in a run-down shack owned by the white man for whom he works "planting, chopping, poisoning, and picking in the cotton field" (Walker 7). In the novel, the family is permanently indebted permanently to the white owner of the cotton fields. Grange in his frustration finds vent to his subservience in drinking, in battering, in ignoring his wife and in being devoid of any emotion.

During the dreary cycle of the Copeland's weekly life together, Grange takes on animalistic traits. He spends the early part of each week recovering from the weekend's drunken splurge. By Thursday, however, the gloom of his situation has overtaken him once more and, animal-like, he stalks the house and swings from the rafters of the porch. By Friday, he is in a stupor from the work and the sun. On Saturday Grange cleans up and escapes down the road into town and into the arms of his lover, the prostitute Josie, staggering home later Saturday night "lurching drunk, threatening to kill his wife and Brownfield, stumbling and shooting off his shot gun" (Walker 12), while his wife, Margaret, and his son terrorized, hide in the woods.

On Sunday morning, he goes to church and raises "his voice above all the others... in song and in prayer" (Walker 13) and by nightfall both Grange and Margaret fight again. Monday morning he woke to start the cycle again. During the week, Whenever Grange happens to meet Shipley, the white man in whose field he labours, he sheds off his human traits. Walker tries to depict them through the images of masks and stones. When Shipley arrives in his truck at the end of the workday to collect the picked cotton, Brownfield had witnessed his father's freeze and he becomes a man of silence: For when the truck came his father's face froze into an unnaturally bland mask, curious and unsettling to see. It was as if his father became a stone or a robot. A grim stillness settled over his eyes and he became an object, a cipher, something that moved in tense jerks if it moved at all." (Walker 8)

The ascertained definition of manhood in African American faction as anywhere in the world, the yardstick to prove the worth and value of a man, is to take care of his self and his family and take up the responsibility of his wife and his children. But, Copeland has to live in cowardice and fear of a system; he has to identify himself by the definition of self by others. He breaches the definition of manhood in abandoning his family. He feels relieved about shedding his duties as a father, as a husband and as a breadwinner and finally fails to fit into the expected definition of manhood. He fails to complete the duties and responsibility of a man in a family and he fails to be a man in the society. He does not fulfill the requirements of a complete man because he fails to shoulder the responsibility expected of him. Resigned to his inability to control his own life or that of his wife and son, Grange contemptibly walks away. His first life ends with this desertion for which he got his just deserts.

Throughout the novel, Walker illustrates her own vision of the nature of the soul in transformation. That belief in the possibility of transformation at once makes the individual wholly responsible for his own salvation.Walker believes that a person is not a static product of the environment, but has the possibility of converting to different "lives" generated by transformations of the self. The novel offers a vivid illustration of a man who goes on to transform his life twice until he becomes a "reborn man", one who has achieved "a total triumph over life's misfortunes" (Walker 36). His first reduces him to the level of a "stone or a robot (Walker 8), he is a flaccid and unreceptive man of the environment because his loses his dignity gradually by the treatment he receives from his White master. Since he has lost his self-respect, he is not able to presume himself neither as a responsible husband or a father. Eventually, he abandons his family and goes to North. His experiences in the North, make him,alive and liberated for the first time in his life. Even though he indulges himself in vicious activities, for the first time he does something on his own accord, not dictated by a white system. Grange experiences "a new life" when he feels that he has played a role in the death of the white woman who drowned in Central Park Lake. As Robert Butler opines, "He acquires the strong conviction that such an act of murder has helped him to recover his manhood and self-respect (Walker 153) because it is 
an act of rebellion against an environment intent on morally paralyzing him" (Walker 354).

In New York City, he enters a second stage of rage and rebellion. He reflects on the incident that propels him away from misery and fear towards hate. He watches a young pregnant white woman drown in a pond in a park. He watches the woman being rebuffed by her soldier lover and feels sympathy for her. Witnessing her leave the soldier's money and ring on the ground, he decided to help her by restoring the ring and part of the money, made bold by her pitiable state. But he tries to rescue her from drowning, the woman rejects him, Grange understands the power of rage. As she curses and insults him, he realizes the profundity of his own hatred towards the white. He hated the entire white race. His hatred is imposed by the misery of his life. When she refuses his hand, and drowned, he felt that his unfortunate life is repaid. He felt that he want to live again. After this incident, Grange makes his hatred of whites "his new religion" (Walker 153) and he strongly feels that the "hatred for the whites will someday unite us"(154). But this hatred gives only a false notion about liberation. He forgets the truth that he is the one who is responsible for his wife's suicide, he blames the white of all his problems. He gets rid of the guilt of abandoning his son Brownfield. So he fails to redeem him from the hatred which poisoned his life in the South. He once again becomes "a demon of hate and destruction"(Walker 136).

After leaving the park, he runs through the streets of New York, yelling, "Teach them to hate, if you want them to survive"(Walker 219). He is inflamed by his new found hatred and wants to inspire his fellow oppressed neighbours to hate as well, so that they all may live again. He tries to physically fight each white man he meets and to continue to encourage other African Americans to fight back as well. But he soon realizes that this sort of liberation is not possible because one man alone cannot swerve a community of oppressed people.

After this transformation he tries to make amends for his mistake. He realizes how his desertion of his family has resulted in the suicide of his wife Margaret and tries to help Brownfield's wife Mem. He realizes that racism has impoverished his life and made him guilty of the violence he inflicted on his own family and his child. He perceives that wounds would be healed and redemption is possible only when he admits his sins. He tells his son, "We guilty, Brownfield, and neither one of us is going to move a step in the right direction until we admit
it"(Walker 209). When he admits that he allowed his wife to die and his family to fall apart, he truly takes human responsibility for his past actions. In this way he redeems himself to a radically new life. Butler observes, Grange undergoes a true conversion which genuinely transforms him, because it is only after he returns to Georgia that he recovers his place in a real community, which regenerates his ability to love and allows him to take full moral responsibility for the "sins" which have marred his first two lives (355).

His survival becomes more meaningful when he tried to help Brownfield's family by giving food and money. While Brownfield loses his humanity in the same Grange lost it in his first life, Grange recovers a human self by assuming familial roles which Brownfield discards. He treats Mem with kindness and helps her deliver Ruth on Christmas Day. From the moment, Grange dedicates himself to rescuing her and providing her with a viable family life. Love for Ruth is the fundamental factor responsible for converting Grange to a blossoming new life. "Whereas in his first life he was "smothered" (Walker 9) by dehumanizing society and in his second life he was "frozen" (Walker 145) by his demonic hatred of whites, he now becomes a "reborn man", redeemed by "love"(157). Through the magic of Ruth's miraculous hugs and kisses, he gradually overcomes his suicidal depression. He redeems himself from the numbness which had incapacitated Grange in his two lives through Ruth's redemptive power of love. He nurtures her, protects her, provides her education and educates her with the wisdom of his life's experiences, reeducating himself. An absolute transformation from a life of hatred to a life of love comes over him. Grange's life become whole and complete when he ensures Ruth the spiritual freedom.

\section{REFERENCES}

Bloom, Harold, (1988) ed. Modern Critical Views: Alice Walker. New York: Chelsea House, 1988.

Bradley, David, (1984) Telling the Black woman's Story, New York Times Magazine, 8 January 1984.

Butler,Robert James, (1993) "Visions of Southern Life and Religion in O'Connor's Wise Blood and Walker's Grange Copeland." CLA Journal.36.4: 349-70.

Walker, Alice, (1970) The Third Life of Grange Copeland.New York: Harcourt Brace Jovanovich Publishers. 